\title{
Oil prices and the US effective exchange rate: A hidden cointegration analysis
}

\author{
Panagiotis Rafailidis • Constantinos Katrakilidis* \\ Aristotle University of Thessaloniki, Department of Economics, Greece
}

Received: 14 July 2016

Revised: 29 September 2016

Accepted: 30 September 2016

\begin{abstract}
We investigate the long-run relationship between the US Dollar effective exchange rate and oil prices (WTI) over the period from January 1986 to August 2014.We allow for the relationship to be asymmetric by employing the hidden cointegration technique of Granger and Yoon (2002) and Schorderet (2004). The Quandt - Andrews approach allows accounting for structural breaks. The results reveal an asymmetric long-run relationship between the two markets.
\end{abstract}

Keywords: exchange rate; oil prices; hidden cointegration; structural breaks; U.S.

JEL Classification Codes: C22, C5, F31, Q43

\section{Introduction}

Most of the early studies have established an adverse relationship between oil price changes and variations in main macroeconomic indicators such as GDP, CPI (For the effects of oil price changes to main macroeconomic indicators see Hamilton, 1983; Burbidge and Harrison, 1984; Hooker, 1996) and the unemployment rate (Loungani, 1986; Lee et.al, 1995; Papapetrou, 2001). Several explanations have been offered to interpret these empirical findings. Higher oil prices increase the cost of inputs in the production function and cause a reduction of the output that leads to slower economic growth. According to Bernanke (1983), the volatility of oil prices may cause a rise in uncertainty, leading to postponement of investments. Besides, uncertainty about oil prices may affect economic activity negatively (Elder and Serletis, 2010). Furthermore, increased oil prices may lead to a rise in the money demand (Bohi, 1989; Bernanke et.al, 1997). Brown and Yucel (2002) discuss the channels through which oil prices affect economic activity.

However, the relationship between exchange rates and oil prices has not been considered to such an extent. The link has been primarily studied by Golub (1983) and Krugman (1983a, b). Theoretically, several models have been developed in order to explain the determination of

\footnotetext{
*Corresponding author. E-mail: katrak@econ.auth.gr.

Citation: Rafailidis, P. and Katrakilidis, C. (2016) Oil prices and the US effective exchange rate: A hidden cointegration analysis, Economics and Business Letters, 5(4), 134-144.
} 
exchange rates. They are based on the interest rate parity, the monetary model, the purchasing power parity and the Taylor rule. Therefore, exchange rates are determined by differentials in interest rates, money supply, inflation and output based on the corresponding model specification. Presentation of the models can be found in Frankel and Rose (1995) and Rossi (2013).

Our purpose is to examine the possible dynamic linkages between oil prices and the US effective exchange rate accounting for possible non-linearities. Moreover, our data set, compared to previous research efforts, is extended and captures the recent financial crisis.

The outline of the paper is as follows. Section 2 reviews the literature. Section 3 presents the methodology and discusses the results. Finally, section 4 concludes.

\section{Literature review}

Benassy-Quere et al (2007), using a Vector Error Correction Model (VECM) approach found that rising oil prices lead to an appreciation of the US Dollar. Amano and Van Norden (1998) found a positive long-run relationship between the price of oil and the US exchange rates. Chen and Chen (2007) also found a positive and statistical significant long-run relationship between oil and exchange rates.

Using DOLS estimations Cheng (2008) found that oil price changes have a negative impact in both short and long-run horizon to US exchange rates. Narayan et. al (2008), using various GARCH models found that higher oil prices lead to a depreciation of the US Dollar exchange rate.

Since the linkages between the two variables remain controversial the existence of an asymmetric relationship between oil price changes and exchange rates has also been investigated. According to Enders and Dibooglu (2001), interventions by the monetary authorities may result in asymmetric adjustments in exchange rates. The reason is the different way the authorities may react to a currency appreciation than to a depreciation. Also, Ewing et. al (2006) suggests that asymmetries may be derived from heterogeneous expectations about nominal exchange rates, high transaction costs which restrain or decelerate the adjustment process, economic and political shocks which can affect oil prices and exchange rates differently and institution factors such as the decisions of the Organization of the Petroleum Exporting Countries (OPEC) about pricing and production policies.

Coleman et. al (2010), found evidence in favor of asymmetric cointegration between real exchange rates and real oil prices using a Smooth Transition Regression (STR) model. Ahmad and Hernandez (2013), investigated a group of major oil exporting and importing countries and applying the Threshold Autoregressive (TAR) and the Momentum Threshold Autoregressive (MTAR) models discovered asymmetry in the adjustment process. Akram (2004), evidenced the presence of non-linearities as he found that the effects on the Norwegian exchange rates of oil price changes vary depending on the level and trend of the latter prices. Buetzeret. al (2012), found that the response of exchange rates differs significantly depending on the source of the oil price shocks. Following Kilian's (2009) approach, they divided oil prices in different categories based on supply and demand side shocks.

To sum up, the linkages between the two variables are not quite explicit. We attempt to improve the understanding of this issue by adding new empirical evidence focusing on the detection of possible asymmetries and structural breaks. 
Figure 1. Evolution over time of the REER and ROIL variables.

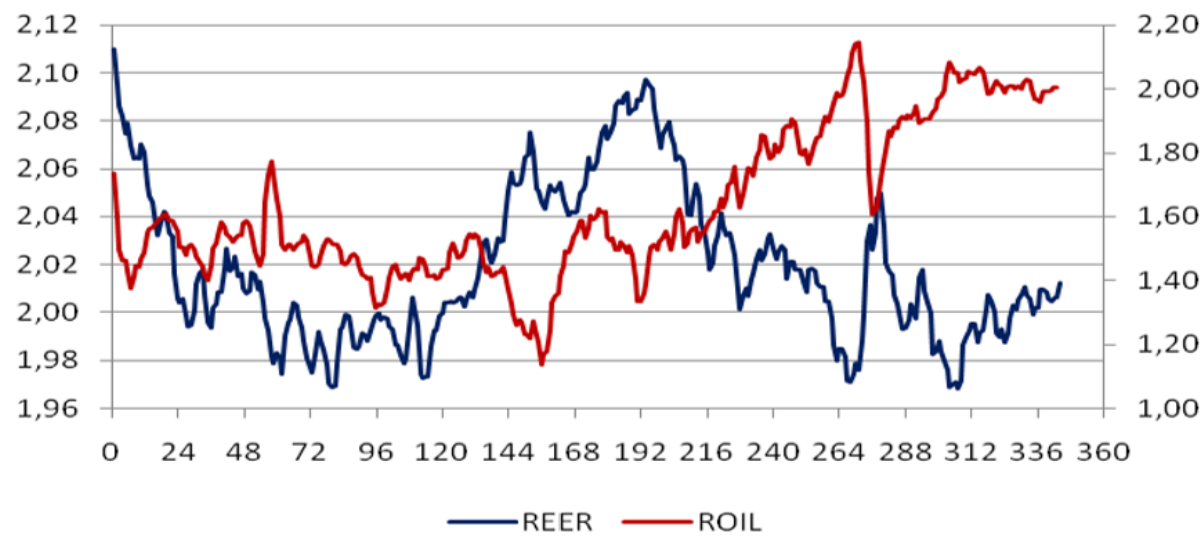

\section{Data and empirical results}

To investigate the relationship between oil prices and real exchange rates we employ the West Texas Intermediate (WTI) oil price index. Historical price data for WTI are taken from the Energy Information Administration. We also use the US Effective Exchange Rate (EER), a weighted average of the country's currency relative to an index or basket of other major currencies. The data are taken from the Federal Reserve Bank of St. Louis. The weights are determined by comparing the relative trade balances, in terms of one country's currency, with each other country within the index. Both variables are monthly, covering the period from 01/1986 to 08/2014 and all prices are real and in logarithmic form. The ROIL and REER denote the real West Texas Intermediate (WTI) oil prices and the real Effective Exchange Rates (EER) of the US Dollar respectively. Figure 1, shows the evolution over time of the two examined variables.

Table 1. Unit root tests results.

\begin{tabular}{|c|c|c|}
\hline \multicolumn{3}{|l|}{ Levels } \\
\hline & PP & KPSS \\
\hline REER & -2.998 & $0.253 *$ \\
\hline ROIL & -2.851 & $0.439 *$ \\
\hline \multicolumn{3}{|l|}{ First differences } \\
\hline & PP & KPSS \\
\hline REER & $-12.725 *$ & 0.118 \\
\hline ROIL & $-16.816 *$ & 0.033 \\
\hline
\end{tabular}

At the first step, it is necessary to test for the integration properties of the series and thus we apply the Phillips and Perron (1988) unit root test (PP) and the Kwiatkowski et al. (1992) stationarity test (KPSS). The results, reported in Table 1, suggest that both variables are nonstationary in levels, while they turn stationary in first differences, at the $1 \%$ significance level.

In the next we apply three different cointegration methods. The conventional cointegration methods of Engle-Granger (1987) and Phillips-Ouliaris (1990), that are based on unit root tests of the residuals of the estimated models and the Johansen's (1991, 1995) Maximum Likelihood (ML) cointegration analysis, which provides two likelihood tests for the presence of 
cointegrating vectors, namely, the trace and the maximum eigen value tests. The estimation results, reported in Table 2, suggest the acceptance of the null hypothesis of no cointegration between the examined variables, at the $5 \%$ significance level for all tests employed.

Table 2. Cointegration tests results.

\begin{tabular}{cc|cc|cc}
\hline \hline \multicolumn{2}{l}{ Dependent variable Exchange rates } & & & \\
\multicolumn{2}{c|}{ Engle Granger } & \multicolumn{2}{c|}{ Philips - Ouiliaris } & & Johansen \\
t-statistic & $\mathrm{Zt}$ & $\mathrm{t}$-statistic & $\mathrm{Zt}$ & Trace test & Max eigenvalue \\
$-3.367176\left(^{\alpha}\right)$ & $-16.575\left(^{\alpha}\right)$ & $-3.367\left(^{\alpha}\right)$ & $-16.575\left(^{\alpha}\right)$ & $10.370\left(\left(^{\beta}\right)\right.$ & $8.296\left(^{\beta}\right)$ \\
\hline \hline
\end{tabular}

Notes:

-The critical values are calculated as described in MacKinnon et al. (1996).

- $\left({ }^{\alpha}\right)$ indicates a model with constant and a deterministic trend.

- $\left({ }^{\beta}\right)$ indicates a model with a linear deterministic trend in the data and a constant in the CE

-*** and *** denote statistical significance at the $1 \%, 5 \%, 10 \%$ level respectively.

Having failed to detect a long-run relationship between the examined series, we proceed by testing for the presence of possible structural breaks. Perron (1989) demonstrated that a break in the deterministic trend reduces the power of standard unit root tests dramatically.

Gregory et al. (1996) showed that the rejection frequency of the ADF test for cointegration falls substantially in the presence of a structural break in the cointegrating relation. We proceed by applying a residual-based cointegration test suggested by Gregory and Hansen (1996a, b), which permits the time of the structural change to be determined by the data, endogenously. We test three model specifications of structural change described as: (i) level shift, (ii) level shift with trend, and (iii) trend and regime shift where trend, level shift and slope coefficients can change. In particular, the tested models are presented below:

$$
\begin{gathered}
\text { REER }_{t}=\alpha_{1}+\alpha_{2} D_{t}+\gamma \text { ROIL }+\varepsilon_{t} \\
\text { REER }_{t}=\alpha_{1}+\alpha_{2} D_{t}+\beta \text { trend }_{t}+\gamma \text { ROIL }+\varepsilon_{t} \\
\text { REER }_{t}=\alpha_{1}+\alpha_{2} D_{t}+\beta_{1} \text { trend }_{t}+\beta_{2} \text { trend }_{t} D_{t}+\gamma_{1} \text { ROIL }+\gamma_{2} \text { ROIL }_{t}+\varepsilon_{t}
\end{gathered}
$$

where $D^{\tau}$ is a dummy variable with $D^{\tau}=0$ for $t<\tau$ and $D^{\tau}=1$ for $t \geq \tau$ and $\tau$ the time of the structural break. The results, reported in Table 3, imply that we cannot reject the null hypothesis

\begin{tabular}{|c|c|c|c|c|c|c|}
\hline \multicolumn{7}{|l|}{ Panel A } \\
\hline \multirow{3}{*}{$\begin{array}{l}\text { Depended } \\
\text { Variables }\end{array}$} & \multicolumn{6}{|c|}{ Model Specification } \\
\hline & \multicolumn{2}{|c|}{ Level break, no trend } & \multicolumn{2}{|c|}{ Level break, trend } & \multicolumn{2}{|c|}{ Regime and trend swift } \\
\hline & t-statistic & $\mathrm{Za}$ & t-statistic & $\mathrm{Za}$ & t-statistic & $\mathrm{Za}$ \\
\hline REER & -4.481 & -41.203 & -5.019 & -42.659 & -5.008 & -38.059 \\
\hline \multicolumn{7}{|l|}{ Panel B } \\
\hline \multirow[t]{2}{*}{$\mathrm{T}_{\mathrm{b}}$} & \multicolumn{2}{|c|}{ Level break, no trend } & \multicolumn{2}{|c|}{ Level break, trend } & \multicolumn{2}{|c|}{ Regime and trend swift } \\
\hline & $10 / 1998$ & 07/1999 & 04/1997 & 07/1999 & $11 / 1998$ & $11 / 1998$ \\
\hline
\end{tabular}
of no cointegration.

Table 3. Gregory Hansen Cointegration tests.

Notes:

- $\mathrm{t}$-statistic denotes the ADF minimum test statistic for a unit root across all possiblebreak points and

Zt denotes the Philips - Perron unit root test respectively.

-The optimal lag length is determined by the Akaike Information Criterion.

- $\mathrm{T}_{\mathrm{b}}$ denotes the time of the break.

-Critical values are tabulated in Gregory and Hansen (1996a, 1996b).

-*** and $* * *$ denote statistical significance at the $1 \%, 5 \%, 10 \%$ level respectively. 
Next, we adopt the hidden cointegration technique as developed by Granger and Yoon (2002) and Schorderet (2004) ${ }^{1}$. This approach allows us to relax the assumption of a common stochastic trend and test for possible different cointegration relationships ${ }^{2}$ among positive and negative changes in exchange rates and oil prices.

Before we proceed, in Table 4 we present the results of the PP unit root and the KPSS stationarity tests for the negative and positive partial sums of the series. Actually the REER ${ }^{+}$, REER ${ }^{-}, \mathrm{ROIL}^{+}$and $\mathrm{ROIL}^{-}$denote the positive and negative partial sums of exchange rates and oil prices respectively. The results imply that all variables are non-stationary when tested in levels, at the 5\% significance level, while in first difference form they become stationary. Hence, the decomposed variables are all integrated of order one I(1).

Table 4. Unit root tests of the decomposed series.

\begin{tabular}{|c|c|c|}
\hline \multicolumn{3}{|l|}{ Levels } \\
\hline & PP & KPSS \\
\hline REER+ & 0.414 & $2.236^{*}$ \\
\hline REER- & -1.146 & $2.206^{*}$ \\
\hline ROIL+ & 0.262 & $2.222 *$ \\
\hline ROIL- & -0.914 & $2.230 *$ \\
\hline \multicolumn{3}{|l|}{ First differences } \\
\hline & $\mathrm{PP}$ & KPSS \\
\hline REER+ & $14.115^{*}$ & 0.080 \\
\hline REER- & $-14.449 *$ & 0.216 \\
\hline ROIL+ & $-12.763 *$ & 0.170 \\
\hline ROIL- & $-11.046 *$ & 0.077 \\
\hline
\end{tabular}

Notes:

-PP is the Phillips Perron test and KPSS the Kwiatkowski-Phillips-Schmidt-Shin test.

- The model contains a constant and without deterministic trend.

$-*, * *$ and $* * *$ denote statistical significance at the $1 \%, 5 \%, 10 \%$ level respectively.

In the next step, we proceed with testing for possible hidden cointegration. The employed methodology allows us to search for a long-run relationship between the positive and negative components of the variables. In this direction we estimate the following equations.

$$
\begin{aligned}
& R_{E E R_{t}^{+}+\Delta R E E R_{t}^{-}}=\alpha^{+}+\beta^{+} \text {trend }_{t}+\gamma^{+} \text {ROIL }^{+}+\varepsilon_{1 t} \\
& \text { REER }_{t}^{+}+\Delta R E E R_{t}^{-}=\alpha^{-}+\beta^{-} \text {trend }_{t}+\gamma^{-} \text {ROIL }^{-}+\varepsilon_{2 t} \\
& \text { REER }_{t}^{-}+\Delta R E E R_{t}^{+}=\alpha^{+}+\beta^{+} \text {trend }_{t}+\gamma^{+} \text {ROIL }^{+}+\varepsilon_{3 t} \\
& \text { REER }_{t}^{-}+\Delta R E E R_{t}^{+}=\alpha^{-}+\beta^{-} \text {trend }_{t}+\gamma^{-} \text {ROIL }^{-}+\varepsilon_{4 t}
\end{aligned}
$$

\footnotetext{
${ }^{1}$ The method we used has been suggested by Schorderet (2004) to improve the hidden cointegration technique that has been originally proposed by Granger and Yoon (2002) and is justified by the nonlinear properties of partial sums of the series. According to Schorderet (2004) the OLS estimators although consistent, are likely to be biased in finite samples, therefore, he suggested the specification we used to overcome this problem.

${ }^{2}$ The cointegration models were developed by Engle and Granger (1987) but do not underline in all the cases the link between two, non-stationary time series. Thus, the asymmetric cointegration models emerged. The hidden cointegration represents a particular case of asymmetric cointegration and shows that we may observe common dynamics of time series, in their positive and/or negative components. It allows for distinct cointegration relationships between subcomponents of time series, even when cointegration between them is not identified (Honarvar, 2009). Therefore, we use the hidden cointegration approach as developed by Granger and Yoon (2002) and Schorderet (2004).
} 
Table 5. Hidden Cointegration.

Panel A

\begin{tabular}{ccc}
\multicolumn{3}{c}{ Model specification 1 } \\
Variable & REER $_{t}^{+}+\Delta R E E R_{t}^{-}=\alpha^{+}+\beta^{+}$trend $_{t}+\gamma^{+}$ROIL $^{+}+\varepsilon_{t}$ & \\
ROIL $^{+}$ & Coefficient & t-Statistic \\
$\alpha^{+}$ & -0.003 & -0.725 \\
trend $_{\mathrm{t}}$ & $-0.025^{*}$ & -14.366 \\
& $0.002^{*}$ & 37.929
\end{tabular}

Residual based Cointegration tests

Engle - Granger $-4.561\left({ }^{\beta}\right)^{*}$

Quandt-Andrews stability test

\begin{tabular}{lc} 
Max LR F-stat (10/2008) & 85.125 \\
Max Walt F-stat (10/2008) & 255.375 \\
\hline Panel B & Model specification 2 \\
& REER $_{t}^{+}+\Delta R E E R_{t}^{-}=\alpha^{-}+\beta^{-}$trend $_{t}+\gamma^{-} \mathrm{ROIL}^{-}+\varepsilon_{t}$
\end{tabular}

Variable

ROIL -

$\alpha^{-}$

trend $_{\mathrm{t}}$

Coefficient

$-0.064 *$

$-0.035^{*}$

$0.001 *$

Phillips - Ouliaris $-4.581\left({ }^{\beta}\right)^{*}$

0.000

0.000

$\mathrm{t}-$ Statistic

$-8.205$

$-19.057$

16.181

\section{Engle - Granger}

$-5.089\left({ }^{\beta}\right)^{*}$

Residual based Cointegration tests

$-5.089\left({ }^{\beta}\right)^{*}$

Max LR F-stat (09/2006)

Quandt-Andrews stability test

Phillips - Ouliaris

73.006

0.000

Max Walt F-stat (09/2006)

219.018

\section{Panel $C$}

Model specification 3

$$
\mathrm{REER}_{t}^{-}+\triangle \mathrm{REER}_{t}^{+}=\alpha^{+}+\beta^{+} \text {trend }_{t}+\gamma^{+} \mathrm{ROIL}^{+}+\varepsilon_{t}
$$

Variable

Coefficient

$\mathrm{ROIL}^{+}$

$\alpha^{+}$

trend

Engle - Granger

$-2.800\left({ }^{\beta}\right)$

Max LR F-stat (04/1999)

$-0.089 *$

$-0.080 *$

$-0.001^{*}$

0.000
t-Statistic

$-11.251$

$-25.571$

$-9.823$
Residual based Cointegration tests
Phillips - Ouliaris $-3.028\left({ }^{\beta}\right)$

Quandt-Andrews stability test

\begin{tabular}{ll}
176.682 & 0.000 \\
530.046 & 0.000 \\
\hline
\end{tabular}

Max Walt F-stat (04/1999)

Panel D

\begin{tabular}{lcc} 
& Model specification 4 & \\
Variable & REER $_{t}^{-}+\Delta R E E R_{t}^{+}=\alpha^{-}+\beta^{-}$trend $_{t}+\gamma^{-}$ROIL $^{-}+\varepsilon_{t}$ & \\
ROIL $^{-}$ & Coefficient & t-Statistic \\
$\alpha^{-}$ & $0.067 *$ & 3.807 \\
trend $_{t}$ & $-0.047^{*}$ & -11.344 \\
\hline
\end{tabular}




\begin{tabular}{|c|c|c|}
\hline \multicolumn{3}{|c|}{ Residual based Cointegration tests } \\
\hline $\begin{array}{l}\text { Engle - Granger } \\
-2.264\left({ }^{\beta}\right)\end{array}$ & \multicolumn{2}{|c|}{$\begin{array}{l}\text { Phillips - Ouliaris } \\
-2.138\left({ }^{\beta}\right)\end{array}$} \\
\hline \multicolumn{3}{|c|}{ Quandt - Andrews stability test } \\
\hline Max LR F-stat (01/1998) & 180.683 & 0.000 \\
\hline Max Walt F-stat (01/1998) & 542.051 & 0.000 \\
\hline
\end{tabular}

Following Engle - Granger (1987) and Phillips - Ouliaris (1990), we test the null hypothesis of no cointegration against the alternative of cointegration based on the stationarity of the residuals of the above equations (4-7). The results, presented in tables 5, reveal evidence of hidden cointegration in two cases: In particular, between positive oil price changes and positive exchange rate changes as well as between negative oil price changes and positive exchange rate changes (models 1 and 2).

The adoption of the above long-run estimates assumes their stability over the examined time period, so we further employ the Quandt-Andrews breakpoint test. The test was originally introduced by Quandt (1960) and later developed by Andrews (1993) and Andrews and Ploberger (1994). The Quandt-Andrews breakpoint test is based on a single Chow breakpoint test that is employed on every observation between two dates. The corresponding F-statistics are then summarized into one statistic for a test with null hypothesis that of no breakpoint. In every single Chow test, two statistics are used: the Likelihood Ratio F-statistic and the Walt Fstatistic. Then, the Maximum statistic, the Average and the Exponential transformation of the individual Chow tests are calculated.

The results of the Quandt-Andrews breakpoint test, reported in Table 5, imply that the relationship between oil and exchange rate components, as described in equations (4-7), is not stable, and that a structural break may exist in all cases.

Therefore, once again, we apply the hidden cointegration technique by taking under consideration the structural breaks detected by the Quandt-Andrews test.

The results, reported in table 6 , imply the existence of hidden cointegration in three cases (models 1, 2 and 3). Positive oil prices changes affect exchange rates negatively (Panels 1 and 3 ) while negative oil price changes have a positive effect on exchange rates (Panel 2) in the long-run time horizon. However, we failed to detect a long-run relationship between negative oil price changes and negative exchange rates changes (Panel 4). Regarding the long-run coefficients we found that negative oil price changes have a greater impact $\left(\gamma^{+}=0.068\right)$ on increased exchange rates than that of positive oil price changes $\left(\gamma^{-}=-0.039\right)$ implying the presence of asymmetry in the effects of oil price changes on the exchange rates.

Summing up, the results imply that positive oil price changes have a negative impact in the US exchange rates; in other words, increased oil prices lead to a depreciation of the US Dollar in the long run. On the other hand, negative oil price changes seem to have a long-run relationship only with the positive exchange rate changes. The differences in the estimated cointegration vectors between the positive and negative components imply asymmetry. These results indicate that the US economy is depending on imports more than its major trading partners and therefore increased oil prices may lead to a deterioration of the US current account. Therefore, the US Dollar depreciates in absolute terms more than the currencies of its major trading partners. The presence of asymmetry can be explained by several sources, such as monetary policy, but further research is needed. However, we cannot eliminate the possibility 
that what we observe is a result of a portfolio re-balancing mechanism as investors, in order to limit their exchange rate exposure, try to manage their risk (Hau and Rey, 2004).

Table 6. Hidden Cointegration.

\section{Panel A}

$\begin{array}{ccc} & \text { Model specification 1 } & \\ & \text { REER }_{t}^{+}+\Delta R E E R_{t}^{-}=\alpha_{1}^{+}+\alpha_{2}^{+} D_{t}+\beta^{+} \text {trend }_{t}+\gamma^{+} \text {ROIL }^{+}+\varepsilon_{t} \\ \text { Variable } & \text { Coefficient } & \text { t-Statistic } \\ \text { ROIL }^{+} & -0.039^{*} & -9.451 \\ \alpha_{1}^{+} & -0.023^{*} & -17.608 \\ D_{t}(10 / 2008) & 0.034^{*} & 15.371 \\ \text { trend }_{t} & 0.002^{*} & 50.702\end{array}$

\begin{tabular}{|c|c|c|}
\hline $\begin{array}{c}\text { Engle - Granger } \\
-5.671\left({ }^{\beta}\right)^{*}\end{array}$ & \multicolumn{2}{|c|}{$\begin{array}{l}\text { Phillips - Ouliaris } \\
\qquad-5.494\left({ }^{\beta}\right)^{*}\end{array}$} \\
\hline \multicolumn{3}{|l|}{ Panel B } \\
\hline \multicolumn{3}{|c|}{ Model specification 2} \\
\hline \multicolumn{3}{|c|}{$R E E R_{t}^{+}+\Delta R E E R_{t}^{-}=\alpha_{1}^{-}+\alpha_{2}^{-} D_{t}+\beta^{-}$trend $_{t}+\gamma^{-} R O I L^{-}+\varepsilon_{t}$} \\
\hline Variable & Coefficient & $\mathrm{t}$-Statistic \\
\hline$R O I L^{-}$ & $-0.068 *$ & -8.623 \\
\hline$\alpha_{1}^{-}$ & $-0.038 *$ & -18.057 \\
\hline$D_{t}(09 / 2006)$ & $-0.005^{*}$ & -2.577 \\
\hline trend $_{t}$ & $0.001 *$ & 15.887 \\
\hline
\end{tabular}

\begin{tabular}{cc} 
& Residual based Cointegration tests \\
Engle - Granger & Phillips -Ouliaris \\
$-5.212\left({ }^{\beta}\right)^{*}$ & $-5.083\left({ }^{\beta}\right)^{*}$ \\
\hline \hline
\end{tabular}

Panel C

Model specification 3

\begin{tabular}{|c|c|c|}
\hline \multicolumn{3}{|c|}{$R E E R_{t}^{-}+\Delta R E E R_{t}^{+}=\alpha_{1}^{+}+\alpha_{2}^{+} D_{t}+\beta^{+}$trend $_{t}+\gamma^{+} R O I L^{+}+\varepsilon_{t}$} \\
\hline Variable & Coefficient & t-Statistic \\
\hline ROIL $^{+}$ & $-0.069 *$ & -11.930 \\
\hline$\alpha_{1}^{+}$ & $-0.077^{*}$ & -33.801 \\
\hline$D_{t}(04 / 1999)$ & $0.037 *$ & 17.974 \\
\hline trend $_{t}$ & $-0.001 *$ & -17.688 \\
\hline
\end{tabular}

Residual based Cointegration tests

Engle - Granger Phillips -Ouliaris

$-4.317\left({ }^{\beta}\right) * * \quad-4.176\left({ }^{\beta 3}\right) * *$

Panel D

Model specification 4

$\begin{array}{ccc} & \text { REER }_{t}^{-}+\Delta R E E R_{t}^{+}=\alpha_{1}^{-}+\alpha_{2}^{-} D_{t}+\beta^{-} \text {trend }_{t}+\gamma^{-} \text {ROIL }^{-}+\varepsilon_{t} \\ \text { Variable } & \text { Coefficient } & \text { t-Statistic } \\ \text { ROIL } & 0.075^{-} & 6.603 \\ \alpha_{1}^{-} & -0.050^{*} & -18.362 \\ D_{t}(01 / 1998) & 0.045^{*} & 21.731\end{array}$




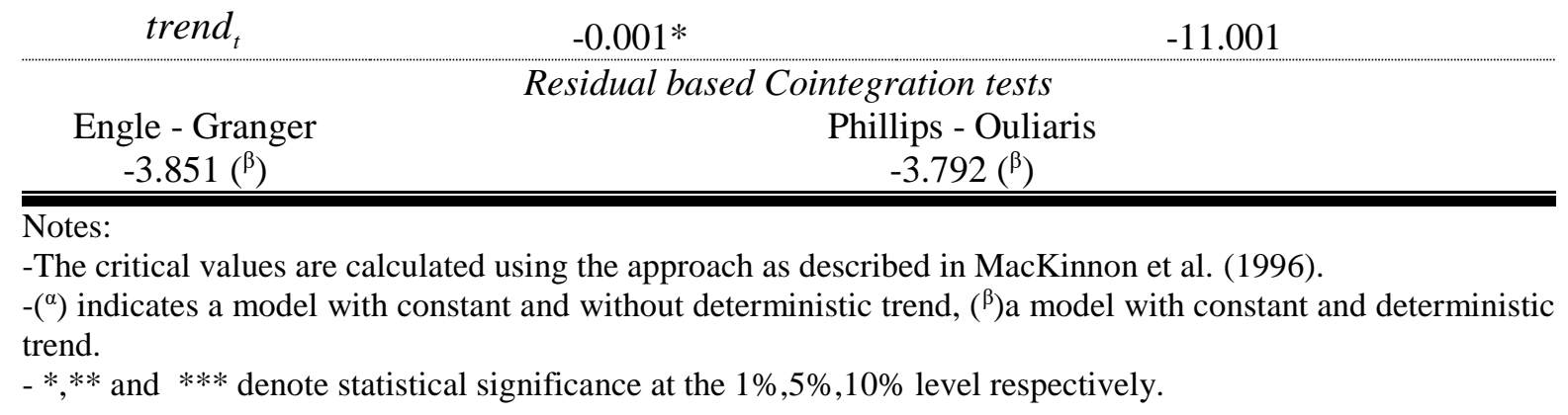

\section{Conclusions}

In this paper we investigated the links between oil prices and exchange rates. For this purpose in the first step we employed the Engle-Granger (1987), Phillips-Ouiliaris (1990) and Johansen (1991, 1995) cointegration technique. The results from all methods indicated that there is no long-run relationship between the investigated markets.Furthermore, using the Gregory and Hansen (1996a, b) approach to account for structural breaks, we confirmed the previous results. However, using the hidden cointegration method of Granger and Yoon (2002) and Schorderet (2004), we found evidence of hidden cointegration. Nevertheless, the Quandt-Andrews break point test revealed that the relationship between the positive and negative oil prices and exchange rate components are not stable and a possible structural break in all equations exists. When the structural breaks were incorporated in the model we found new evidence in favor of hidden cointegration implying that structural breaks should not be ignored. We found that the effects of increased oil prices in exchange rates differ from that of decreased oil prices and confirm that oil price change is a source of asymmetry. The results revealed the existence of three cointegration relationships. In particular we found that increased oil prices affect exchange rates negatively while decreased oil prices have a positive impact in exchange rates. The effects differ among them in size and reveal the presence of asymmetries. Our findings could be important for the understanding of the relationship between oil and exchange rates and could be useful to investors and other market participants, such as financial managers, analysts and firms, in order to manage their investments and minimize their portfolio risks.

\section{References}

Ahmad, A.H., and Hernandez, R.M. (2013) Asymmetric adjustment between oil prices and exchange rates: Empirical evidence from major oil producers and consumers, Journal of International Financial Markets, Institutions \& Money, 27, 306-317.

Akram, Q.F. (2004) Oil prices and exchange rates - Norwegian evidence, Econometric Journal, 7, 76-504.

Amano, R.A., and van Norden, S.( 1998) Oil prices and the rise and fall of the US real exchange rate. Journal of International Money and Finance, 17, 299-316.

Andrews, D.W.K. (1993) Tests for Parameter Instability and Structural Change with Unknown Change Point, Econometrica, 61(4), 821-856.

Andrews, D.W.K., and Ploberger, W. (1994) Optimal tests when a nuisance parameter is present only under the alternative, Econometrica, 62(6), 1383-1414.

Bénassy-Quéré, A., Mignon, V., and Penot, A. (2005) China and the relationship between the oil price and the dollar, CEPII, Working Paper.

Bernanke, B. (1983) Nonmonetary effects of the financial crisis in the propagation of the Great Depression, American Economic Review, 73: 257-276. 
Bernanke, B.S., Gertler, M., and Watson, M. (1997). Systematic Monetary Policy and the Effects of Oil Price Shocks. Brookings Papers on Economic Activity, 1, 91-157.

Bohi, D.R. (1989) Energy Price Shocks and Macroeconomic Performance, Resources for the Future, Washington, DC.

Brown, P.A.S., and Yücel, M.K. (2002) Energy prices and aggregate economic activity: an interpretative survey, The Quarterly Review of Economics and Finance, 42, 193-208.

Buetzer S, Habib MM, Stracca L. (2012). Global exchange rate configurations: Do oil shocks matter?, European Central Bank, Working Paper No. 1442.

Burbridge, J., and Harrison, A. (1984) Testing for the Effects of Oil-Price Rises Using Vector Autoregressions, International Economic Review, 25(1), 459-484.

Chen, S.S., and Chen, H.C. (2007) Oil prices and real exchange rates, Energy Economics, 29(3), 390-404.

Cheng, K.C. (2008) Dollar depreciation and commodity prices, IMF World Economic Outlook, International Monetary Fund, Washington D.C 72-75.

Coleman, S., Cuestas, J.C., Mourelle, E. (2010) A nonlinear analysis of the relationship between real exchange rates and real oil prices in African countries, CSAE Conference 2010-Economic Development in Africa, 21st -23rd March, St Catherine's College, Oxford.

Dickey, D.A., and Fuller, W.A. (1979) Distribution of the Estimators for Autoregressive TimeSeries with a Unit Root, Journal of American Statistical Association, 74, 427-431.

Elder, J., and Serletis, A. (2010) Oil price uncertainty, Journal of Money, Credit and Banking, 42(6), 1137-1159.

Enders, W., and Dibooglu, D. (2001) Long-Run Purchasing Power Parity with Asymmetric Adjustment, Southern Economic Journal, 68(2), 433-445.

Engle, R.F., and Granger, C.W.J. (1987) Cointegration and error correction: representation, estimation and testing, Econometrica, 55, 251-277.

Ewing, B.T., and Hammoudeh, S.M., and Thompson, M.A. (2006) Examining asymmetric behavior in US petroleum futures and spot prices, Energy Journal, 27, 9-24.

Frankel, J., and Rose, A. (1995). Empirical Research on Nominal Exchange Rates, Handbook of International Economics, 3, 1689-1729.

Golub, S.S. (1983) Oil Prices and Exchange Rates, Economic Journal, 93, 576-93.

Granger, C.W.J., and Yoon, G. (2002) Hidden Cointegration, University of California, San Diego, Working Paper No. 2002-02.

Gregory, A.W., and Hansen, B.E. (1996a) Residual-based tests for cointegration in models with regime shifts, Journal of Econometrics, 70, 99-126.

Gregory, A.W., and Hansen, B.E. (1996b) Tests for cointegration in models with regime and trend shifts, Oxford Bulletin of Economics and Statistics, 58, 555-560.

Gregory, A.W., Nason, J.M., and Watt, D.G. (1996) Testing for structural breaks in cointegrated relationships, Journal of Econometrics 71, 321-341.

Hamilton, J.D. (1983) Oil and the MacroeconomySince World War II, Journal of Political Economy, 91(2), 228-48.

Hau, H, and Rey, H. (2004) Can Portfolio Rebalancing Explain the Dynamics of Equity Returns, Equity Flows, and Exchange Rates?, American Economic Review, 94, 126-133.

Honarvar, A. (2009). Asymmetry in retail gasoline and crude oil price movements in the United States: an application of hidden cointegration technique, Energy Economics, 31: 395402.

Hooker, M.A. (1996) What Happened to the Oil Price-Macroeconomy Relationship?, Journal of Monetary Economics, 38, 195-213.

Johansen, S. (1991) Estimation and Hypothesis Testing of Cointegration Vectors in Gaussian Vector Autoregressive Models, Econometrica, 59, 1551-1580. 
Johansen, S. (1995) Likelihood-Based Inference in Cointegrated Vector Autoregressive Models, Oxford University Press, New York.

Kilian, L. (2009) Not all oil shocks are alike: disentangling demand and supply shocks in the crude oil market, American Economic Review, 99(3), 1053- 1069.

Krugman, P. (1983a) Oil and the dollar In Economic Interdependence and Flexible Exchange Rates, MIT Press, Cambridge.

Krugman, P. (1983b) Oil shocks and exchange rate dynamics, in Exchange Rates and International Macroeconomics, University of Chicago Press.

Kwiatkowski, D., Phillips, P.C.B., Schmidt, P., and Shin, Y. (1992) Testing the null hypothesis of stationarity against the alternative of a unit root: How sure are we that economic time series have a unit root?, Journal of Econometrics, 54, 159-178.

Lee, K., Ni, S., and Ratti, R.A. (1995) Oil shocks and the Macroeconomy: The role of price variability, Energy Journal, 16, 39-56.

Loungani, P. (1986) Oil Price Shocks and the Dispersion Hypothesis, Review of Economics and Statistics, 58, 536-539.

Mork, K.A . (1994) Business cycles and the oil market, Energy Journal, 15, 15-38.

Narayan, P.K., Narayan, S., and Smyth, R. (2008) Are oil shocks permanent or temporary? Panel data evidence from crude oil and NGL production in 60 countries, Energy Economics, 30(3), 919-936.

Papapetrou, E. (2001) Oil Price Shocks, Stock Market, Economic Activity and Employment in Greece, Energy Economics, 23, 511-532.

Perron, P. (1989) The great crash, the oil price shock, and the unit root hypothesis, Econometrica, 57(6), 1361-1401.

Phillips, P.C.B., and Ouliaris, S. (1990) Asymptotic Properties of Residual Based Tests for Cointegration, Econometrica, 58(1), 165-193.

Phillips, P.C.B., and Perron, P. (1988) Testing for a Unit Root in Time Series Regression, Biometrica, 75, 335-346.

Pierce, J.L., and Enzler, J.J. (1974). The effects of external in flationary shocks, Brookings Paper on Economic Activity, 1, 13- 61.

Quandt, R.E. (1960) Tests Of The Hypothesis That A Linear Regression System Obeys Two Separate Regimes, Journal of the American Statistical Association 55(290), 324- 330.

Rossi, B. (2013) Exchange Rate Predictability, Journal of Economic Literature, 51, 1063-1119.

Schorderet Y. (2003). Asymmetric Cointegration, Department of Econometrics, University of Geneva, Working Paper No 2003.01, Geneva. 